\title{
ACCOUNT OF A RECENT SPRUCE BUDWORM OUTBREAK IN THE LAURENTIDE PARK REGION OF QUEBEC AND MEASURES FOR REDUCING DAMAGE IN FUTURE OUTBREAKS ${ }^{1}$
}

\author{
By J. R. BLAIS ${ }^{2}$
}

\begin{abstract}
Pulpwood stands in the Laurentide Park region of Quebec were subjected to defoliation by the spruce budworm between 1946 and 1958. Progress of the outbreak was traced from survey records and from radial growth data from 102 localities. The apparent reasons for the temporary reduction in population level from 1951 to 1953, and for the collapse of the infestation in 1958 are discussed. Estimates based on information provided by the various operators in the area place the total amount of merchantable softwoods destroyed at 5.4 million cords, while calculations based on radial growth studies reveal that approximately 1.8 million cords were lost through reductions in increment. About 1.6 million cords were salvaged before the dead wood was rendered unusable by sapwood rots. Measures that would reduce losses from future outbreaks are proposed and discussed.
\end{abstract}

\section{RESUME}

Les peuplements de sapin et d'épinette subirent une forte défoliation causée par la tordeuse des bourgeons de l'épinette de 1946 à 1951 et de 1954 à 1958, dans la région du Parc des Laurentides. La progression de ces invasions a été établie grâce aux données fournies par l'inventaire des insectes forestiers du Ministère des Terres et Forêts de la Province de Québec, et par l'étude des anneaux de croissance provenant d'échantillons de sapins et d'épinettes recueillis dans 102 localités réparties à travers la région. On mentionne les causes probables de la réduction des populations de l'insecte de 1951 à 1953 ainsi que celles qui entraînèrent le déclin de l'infestation.

Grâce aux données fournies par les divers concessionnaires et propriétaires de forêts de la région, on estime que la quantité de bois détruit par linsecte atteint 5.4 millions de cordes, tandis que des études de croissance démontrent que la perte subie par la réduction de l'accroissement serait de 1.8 million de cordes. Il a cependant été possible de récupérer environ 1.6 million de cordes avant que le bois mort ne devienne inutilisable à cause des caries. On propose des mesures qui réduiraient les pertes au cours d'une invasion éventuelle.

\footnotetext{
1 Department of Forestry of Canada, Forest Entomology and Pathology Branch Contribution Number 1018.

2 Forest Research Laboratory, P.O. Box 35, Sillery, Quebec, Canada. Biographical Reference For. Chron. 33.
} 
INTRODUCTION

The most recent series of outbreaks of the spruce budworm, Choristoneura fumiferana (Clem.), in Quebec began in the western part of the Province about 1940. During the following 15 years the outbreaks spread eastward to cover all forest regions where balsam fir, Abies balsamea (L.), Mill, is an important constituent. The last phase in this series of outbreaks in Quebec took place in the Lower St. Lawrence and the Gaspé Peninsula, and has already been described in some detail (Blais and Martineau, 1960). Elsewhere in the Province, only limited observations were made during the outbreaks.

In 1960 , studies were undertaken to assemble what information could still be obtained on the recent outbreak in the Laurentide Park region. Because of the recurring nature of spruce budworm outbreaks, their history can be of great value. Knowledge on the development, duration, and damage caused by one outbreak can, in many ways, indicate measures that would reduce both the danger of future outbreaks and the losses from them. It is with this in mind that the present information was compiled.

General Description of the Study Area.

The study area covers approximately 10,000 square miles and is formed by a triangle bounded to the northeast and the southeast by the Saguenay and St. Lawrence rivers and the west by the Lake St. John railroad (Fig. 1). Nearly 90 per cent of this area is forested and its ready accessibility makes it one of the most important sources of pulpwood and sawlogs in Quebec. Although the Laurentide Park region represents but a small fraction of the total forested area of the Province, between 15 and 20 per cent of the wood cut in Quebec in recent years has originated from this source.

About 80 per cent of the study area is public domain and under lease to fifteen different woods operating companies; the remainder is privately owned. Eighty five per cent of the area under lease is held by five large woods operators.

Much of the Laurentide Park region is mountainous, and many points reach altitudes between 3,000 and 4,000 feet. It is mostly in the Section B.1(a) of the Boreal Region (Rowe, 1959). The forest is predominantly coniferous with balsam fir and black spruce the primary species. Halliday and Brown (1943) include this general region in that showing the highest balsam fir content in eastern North America. Because the extreme northern and the southwestern sectors are at lower elevations they are subject to a more temperate climate and support a forest of a mixed nature belonging to the Great Lakes-St. Lawrence Region (Rowe, 1959).

Certain parts of the forest have been exploited for many years but in others the mountainous terrain discouraged operations until recently. Consequently, limited amounts of virgin forest still remain.

\section{METHoDs}

Information on the outbreak was obtained from two sources: records provided by private companies and the provincial government, and special radial-growth studies made by the author. 


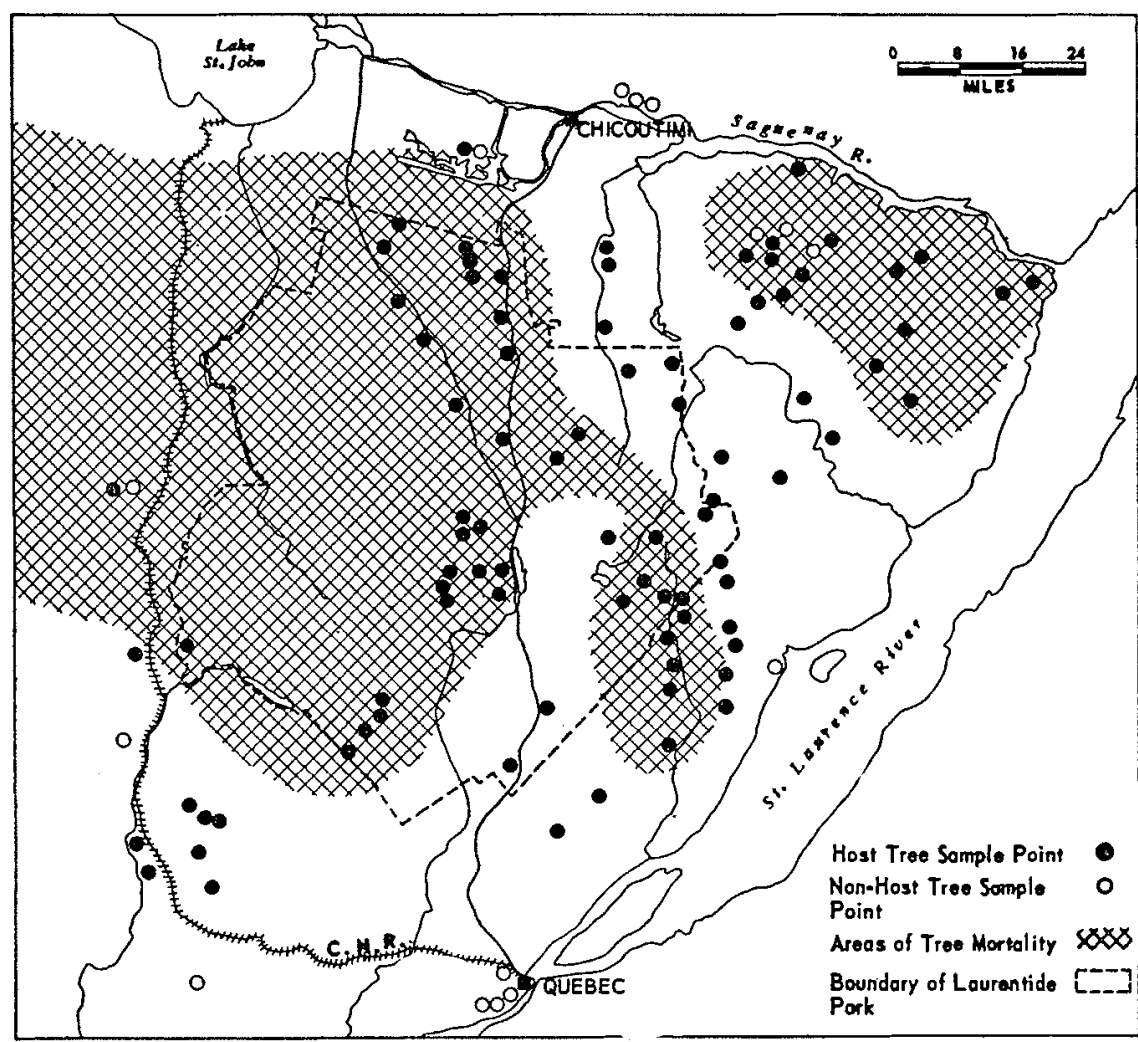

FIGURE 1. Locations in the Laurentide Park Region where basal discs were obtained for radialgrowth studies of spruce budworm host and non-host trees, and areas where tree mortality occurred as a result of defoliation by the spruce bud-worm from 1946 to 1957.

Most companies were able to furnish information on the forest composition prior to the spruce budworm outbreak, the amount of direct loss from tree mortality, and the amount of wood salvaged within their operating limits. One or two companies had detailed information on the outbreak itself. Information on budworm outbreaks for the Province as a whole has been compiled by the Bureau of Entomology of the Quebec Department of Lands and Forests for a number of years. These records are based not so much on direct observations, but rather on insect samples obtained by the Quebec Forest Insect Survey. This information proved valuable in reconstructing the defoliation history for the Laurentide Park Region. Most roads in the study area were travelled during the summers of 1960 and 1961 , and direct observations were made on the extent of tree mortality resulting from the outbreak. Weather records were studied in search of an explanation for the pronounced population fluctuations that took place during the outbreak. 
Tree discs were obtained from living balsam fir trees in 50 locations; white spruce, Picea glauca (Moench) Voss in 33 locations, and black spruce, Picea mariana (Mill.) BSP. in 4 locations, to obtain information on the degree and duration of radial-growth suppression. Discs were also obtained from white pine, Pinus strobus L., from 15 locations; this species being a non-host tree acted as a control (Fig. 1). In addition to the discs taken at stump height at all locations, discs were also taken from the upper third of the crown at 16 locations. Since radial growth in the upper crown is more sensitive to defoliation than in the lower trunk (Mott et al., 1957), these samples permitted a more accurate determination of the first year of severe defoliation, and of major fluctuations in defoliation. At each location, basal discs were taken from five trees of the same species. The upper crown discs were obtained from 7 to 15 trees at each location. Ring-growth measurements were made and analysed according to methods described by Blais (1962).

\section{DeVelopment of THE OUTBREAK}

The spruce budworm feeds almost exclusively on the current shoot growth of the host trees, and defoliation of the current year's growth is generally a good criterion of abundance. The extent of moderate to severe (from 50 to 100 per cent) defoliation for each year of the outbreak is shown in Fig. 2. The radial growth data were generally in close agreement with information obtained from the Quebec Forest Insect Survey. However, the degree and duration of growth suppression for some localities indicated a more severe and prolonged outbreak period than was evident from the Survey returns.

The decline in insect numbers between 1950 and 1954 is perhaps the most unusual feature of this outbreak. Population levels often fluctuate somewhat from year to year during a budworm outbreak, but a decline as pronounced and prolonged as the one under discussion has not been recorded previously. Adverse weather seems to be the only factor that could have brought this about. The short growth period in this region would appear to afford marginal conditions for budworm development; as frosts frequently occur in any month of the year. It has been observed elsewhere how late spring frosts (Blais, 1957) or cool summers (Blais, 1958a) can seriously influence development and survival of this insect. However, a careful study of weather records failed to reveal any general conditions or special events that could definitely explain the recession. Exactly what brought about this very pronounced and prolonged decline from 1950 to 1954 will probably never be known. The resurgence in 1954 apparently was the result of a reinvasion from persistent outbreak areas at lower altitudes to the west (Fig. 2).

The final decline of the outbreak started in 1956 and was complete by 1958. In 1956, temperatures from May to August were sufficiently cool in eastern Canada to prevent the budworm from completing its life cycle in high altitude areas in the Gaspé Peninsula (Blais, 1958a). The average temperature for 10 stations in the Laurentide Park Region for the summer months was four degrees below normal in 1956 and similar to those in the 

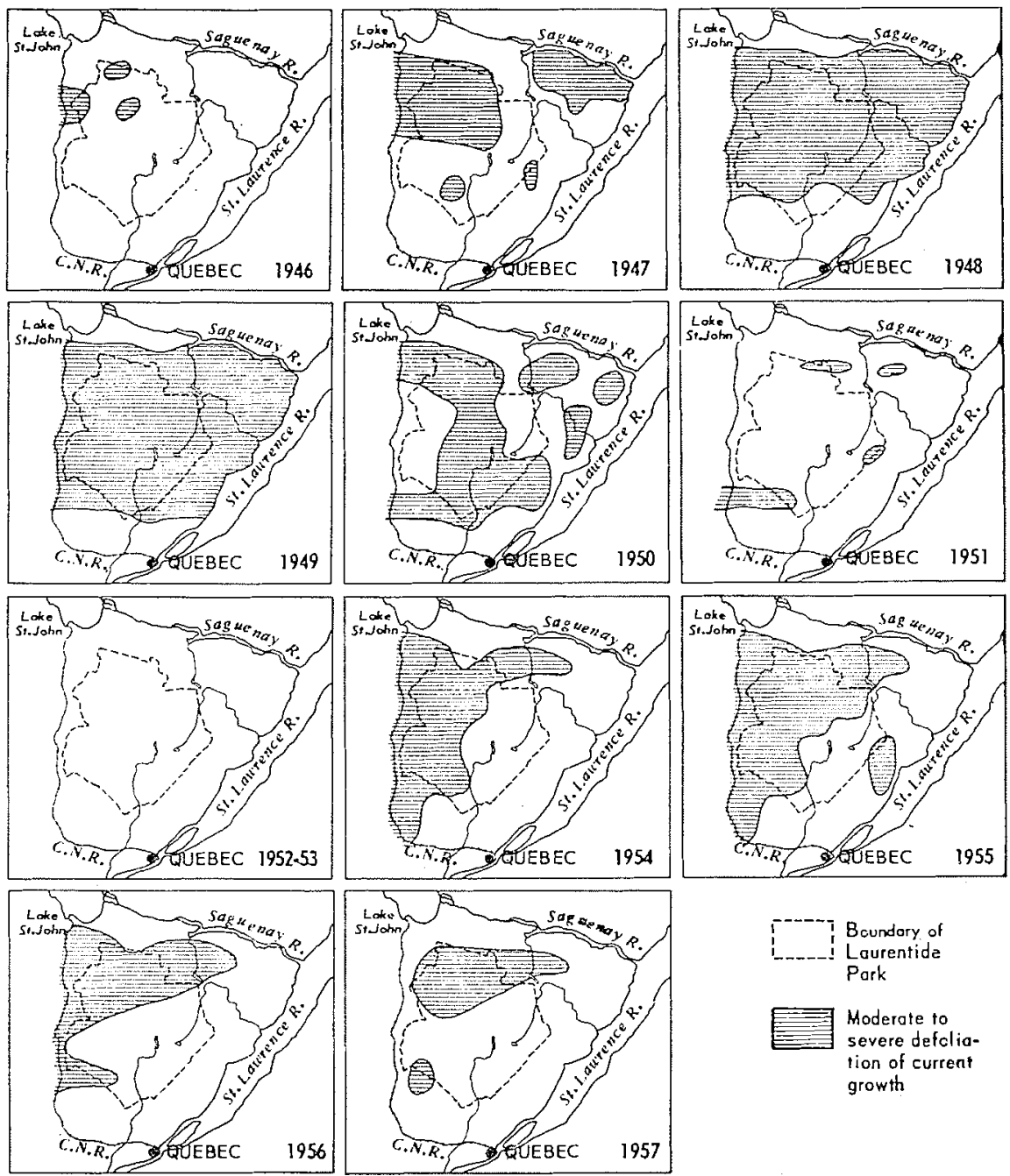

Park

FIGURE 2. Areas of moderate to severe defoliation by the spruce budworm in the Laurentide Park Region, Quebec, from 1946 to 1957.

Gaspé Peninsula, therefore it is unlikely that many budworms completed development at high elevations in the Park in 1956. However, this unfavourable weather was only partially responsible for the decline of the outbreak. By this time a high proportion of the mature balsam fir trees had been killed and the resulting food shortage was undoubtedly another important factor. 


\section{DAMAGE}

The total damage caused during a spruce budworm outbreak is very difficult to determine. In addition to the obvious direct losses, there are numerous indirect losses that are not easily measured. For instance, many trees and many small stands that survive an outbreak cannot be cut because of their isolation in dead and deteriorated stands. In this report only the losses resulting from the mortality of trees of merchantable size and from reductions in increment will be discussed.

Tree mortality which usually results from four to five years of severe defoliation occurred where stands were subjected to two periods of defoliation (Fig. 1). Radial growth data revealed that growth had only partially recovered before the second period of defoliation (Fig. 3). This weakened condition greatly increased the vulnerability of trees to the second attack. Estimates of the amounts of potential pulpwood destroyed were based on fairly complete surveys for about 40 per cent of the study area, and on general reconnaissance surveys of most of the remainder. The amount of mortality for two small areas representing approximately five per cent of the region for which no data were available was calculated by making general comparisons along roads adjoining areas of known mortality. To avoid disclosing information on losses and amounts salvaged for individual limits, the data were combined for the region as a whole and only the total figures will be discussed. The estimated total amount of merchantable wood destroyed for the whole region was 5,400,000 cords. Damage was most severe in mature stands with a high balsam fir content. A few scattered white spruce trees were killed while practically no mortality occurred in black spruce stands. Tree mortality started in 1953 and continued until 1961 well after the collapse of the outbreak. The amount of wood salvaged was close to $1,600,000$ cords which means that about $3,800,000$ cords were lost. The amount of wood salvaged depended not only on accessibility but on the cutting policy of various operators. Some operators salvaged 75 per cent of the volume of dead trees on their limits while others recovered but a small fraction. Much of the dead timber was cut four and five years after death, indicating that deterioration of budworm-killed fir in this region is apparently slower than in northwestern Ontario where salvage is practicable only for about two years after death (Basham and Belyea, 1960). This can probably be attributed to differences in climate between the two regions.

The losses mentioned above were based only on trees of merchantable size. Smaller trees were also killed, mostly where they were intermixed with mature trees, but some mortality also took place in even-aged immature stands (Hatcher, 1964). Despite some mortality of advanced growth in mature stands, stocking for the most part is now very good. However, in some immature stands it may be inadequate.

Practically all the surviving balsam fir, white spruce, and black spruce trees suffered some loss in increment. Estimates of this loss were obtained through radial growth studies. As far as is known, this is the first attempt to estimate this type of spruce budworm damage. The calculations were based on the assumption that the per cent loss in increment at breast height 
was proportional to the per cent loss in volume. Since radial growth patterns at breast height and in the upper crown did not differ greatly (Fig. 3), suppression was apparently uniform enough throughout the tree to justify this assumption.

The average annual radial growth at breast height for the ten years preceding the outbreak was compared with the average for the period of suppression for each of the three host tree species (Table 1). It should be noted that the period of growth suppression was not synchronized in time with the outbreak period but began some years after the initial severe defoliation and persisted some years after the collapse of the outbreak. The average annual growth for white pines from 1936 to 1945 was $1.47 \mathrm{~mm}$., and from 1950 to 1960 (the period of suppression in the budworm host trees) it was $1.61 \mathrm{~mm}$., an increase of 10 per cent. This indicates that conditions for tree growth during the outbreak period were probably as good if not better than during the preceding decade and that the growth losses in the host trees can logically be credited entirely to budworm feeding.

\section{TABLE 1}

Average Radial Growth at Breast Height from 1936 to 1945, and for THE Years OF GROWTH SUPPRESSION DUe to Budworm Defoliation for Balsam Fir, White Spruce, and Black Spruce Trees From Various Locations in the LaURentide Park Region

\begin{tabular}{|c|c|c|c|c|c|c|}
\hline Species & $\begin{array}{c}\text { No. of } \\
\text { trees } \\
\text { sampled }\end{array}$ & $\begin{array}{c}\text { No. of } \\
\text { Iocations }\end{array}$ & $\begin{array}{c}\text { Av. yearly } \\
\text { radial Erowth } \\
1936-45 \\
\text { in } \mathbf{m m} . \\
\end{array}$ & $\begin{array}{c}\text { Years of } \\
\text { growth } \\
\text { suppression }\end{array}$ & $\begin{array}{l}\text { Av. yearly } \\
\text { radial growth } \\
\text { during period } \\
\text { of suppession } \\
\text { in mm. }\end{array}$ & $\begin{array}{l}\text { Av. per cent } \\
\text { reduction } \\
\text { for years } \\
\text { of growth } \\
\text { suppression } \\
\end{array}$ \\
\hline \multicolumn{7}{|l|}{ Balsam } \\
\hline fir & 237 & 50 & 1.51 & $1950-1960$ & 0.82 & 46 \\
\hline White & & & & & & \\
\hline spruce & 164 & 33 & 1.31 & $1950-1960$ & 0.84 & 36 \\
\hline \multicolumn{7}{|l|}{ Black } \\
\hline spruce & 20 & 4 & 0.94 & $1951-1957$ & 0.77 & 18 \\
\hline
\end{tabular}

To arrive at an estimate of the total loss due to growth suppression, the average per cent reduction for each tree species for the outbreak period was applied to the normal annual increment for the whole region. Lachance (1954) calculated the total amount of merchantable softwoods and the allowable annual cut of softwoods for 13 groups of watersheds in Quebec based on conditions in 1950. Two of these watershed groups (numbers 7 and 8) cover approximately 85 per cent of the study area, and these data were therefore used for the area as a whole. On this basis there were approximately 32 million cords of merchantable softwoods with a yearly net allowable cut of 450,000 cords in 1950. Data provided by the operators indicate that, prior to the outbreak, balsam fir, white spruce, and black spruce accounted for approximately 66,6 , and 28 percent of the softwoods respectively. Other species represented less than one per cent. Using these 


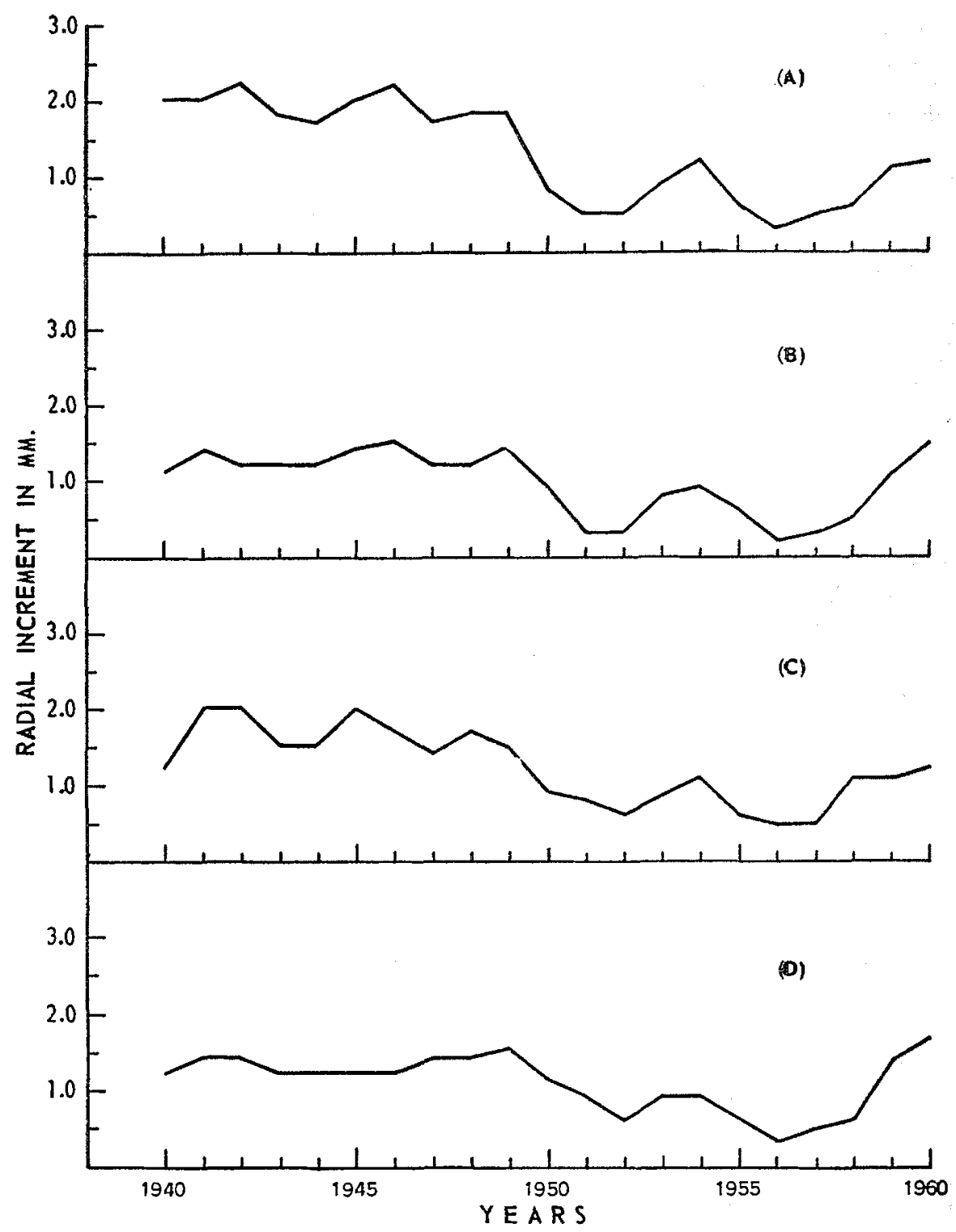

FIGURE 3. Average radial-growth measurements from 1940 to 1960 from basal discs (A) and upper-crown discs (B) from five balsam fir trees from Bailloquet Lake, and from basal discs (C) and upper-crown discs (D) from five black spruce trees from Juneau Lake. Both species show two successive periods of growth reductions; the general accord between discs from the basal and from the upper portions of the stems is evident. 
figures the annual growth can be considered as consisting of 297,000 cords of balsam fir, 27,000 cords of white spruce, and 126,000 cords of black spruce. As shown in Table 1 the annual increment was reduced by an average of 46 per cent for 11 years for balsam fir, by 36 per cent for 11 years for white spruce, and by 18 per cent for 7 years for black spruce. Since the trees that succumbed during the outbreak were also subjected to loss of increment prior to their death, the total increment loss must be calculated on all trees present before mortality occurred. The calculated reductions in Table 1 were based solely on data from trees that survived the outbreak and it was assumed that the trees that died (26 per cent by volume of the balsam fir) suffered at least as much loss in increment as those that survived. The estimated loss in increment for the whole region therefore amounts to $1,502,000$ cords for balsam fir, 107,000 cords for white spruce, and 159,000 cords for black spruce, or a total loss of $1,768,000$ cords of softwoods. Combined with the $3,800,000$ cords of dead trees not salvaged, the total real loss during the outbreak amounted to 5,568,000 cords. This almost equals the annual cut of pulpwood in Quebec and occurred in an area that represents only three per cent of the accessible forest land in the Province!

\section{Discussion and Conclusions}

The periodicity of spruce budworm outbreaks is not sufficiently regular to predict with certainty when an outbreak can be expected in any one region. However, it is known that two prerequisites are required before the spruce budworm reaches outbreak proportions; there must be extensive stands of mature balsam fir, and the weather conditions must be favourable. Considerable amounts of mature balsam fir were destroyed during the recent outbreak in central Quebec and the forests there will probably not be susceptible for at least another 30 years. The periods of early summer drought which are associated with the release of spruce budworm outbreaks (Wellington et al., 1950; Greenbank, 1956; Pilon and Blais, 1961) occur at fairly frequent intervals but cannot be predicted. The first time that a series of years of early summer drought does occur in central Quebec after 1985 could mark the beginning of the next spruce budworm outbreak. This future outbreak is not likely to originate in the Park, because of the marginal weather conditions but will probably arise to the west as during the last outbreak.

The recent outbreak resulted in heavy losses and seriously disrupted operations of a number of operators. The ever increasing value of pulpwood stands in such readily accessible regions will certainly increase the importance of any future losses from budworm depredations. Much of the recent loss could have been avoided, and it would be unfortunate if this experience did not serve a useful purpose.

It is not generally appreciated that spruce budworm infestations originate in extensive stands of mature balsam fir, and that it is precisely these stands that suffer the most severe damage. In such an intensively operated region as the Laurentide Park, no large sectors should remain without a road system and no extensive tracts of mature balsam fir need be allowed to develop. In the advent of another outbreak, losses can be reduced 
to a minimum if emergency measures are applied. The measures which are appropriate to the Laurentide Park Region are probably applicable to the many regions of eastern North America periodically subjected to spruce budworm outbreaks.

Measures that would reduce damage by future budworm outbreaks would have to be applied promptly. In the past, delays have resulted in losses equivalent to millions of cords of pulpwood. Advantage can be taken of the past trend of infestations of the spruce budworm progressing from west to east. The period of pre-salvage for any area could be greatly extended by closely following the development of outbreaks in areas to the west. Since extensive stands of mature balsam fir suffer the most and earliest damage, cutting operations could be concentrated in these most susceptible stands when a spruce budworm outbreak is imminent.

When an outbreak is clearly underway, tree mortality will occur after five to six years of severe attack (Belyea, 1952; Blais, 1958b). Cutting operations will then rapidly pass from the pre-salvage to the salvage stage. In this region balsam fir remains sound for at least four years after death. Pre-salvage and salvage operations for any one locality therefore could extend over a period of about 10 years from the first year of severe defoliation. This period would be even longer for a region such as the Laurentide Park because all localities would not be attacked simultaneously, nor would the degree of infestation be uniform for all localities. With adequate warning, of an impending outbreak and by taking full advantage of the pre-outbreak, outbreak, and post-outbreak periods to adjust cutting operations, the staggering losses of previous outbreaks could largely be avoided.

Operators with cutting rights in various parts of the Province might also modify their cutting programs to obtain the maximum benefits of pre-salvage and salvage operations. Wherever possible, operations should be concentrated in limits under attack. This policy permitted the salvage of 75 per cent of the 600,000 cords of pulpwood killed by the budworm on one company's holdings during the last outbreak.

Aerial application of insecticides can also be used to extend the salvage period. In both New Brunswick and Quebec budworm damage has been greatly reduced by this emergency technique (Webb et al., 1959; Blais and Martineau, 1960) but not without additional cost and some hazard to other natural resources.

The intensive logging operations in such areas as the Laurentide Park Region will help create stands less vulnerable than those of the past, but fairly extensive tracts of inaccessible mature and overmature forests will continue to exist in Quebec for some time yet and form the epicentres of future outbreaks. Prompt recognition of these conditions followed by the type of actions described above could greatly reduce future losses.

\section{ACKNOWLEDGMENTS}

All the woods operators in the region under study were most co-operative in furnishing pertinent data. Mr. Julien Dumais, Technician, Forest Research Laboratory, Quebec, ably assisted in the collection of the radial-growth 
data. The manuscript was reviewed and criticized by colleagues at this laboratory and by Dr. M. L. Prebble and Dr. B. M. McGugan; I wish to thank them.

\section{REFERENCES}

BASHAM, J. T. and R. M. BELYEA. 1960. Death and deterioration of balsam fir weakened by spruce budworm defoliation in Ontario. Part III. The deterioration of dead trees, Forest Sci. 6: 79-96.

BELYEA, R. M. 1952. Death and deterioration of balsam fir weakened by spruce budworm in Ontario. Part II. An assessment of the rôle of associated insect species in the death of severely weakened trees. J. Forestry 50: 729-738.

BLAIS, J. R. 1957. Some relationships of the spruce budworm to black spruce. For. Chron. 33: $364-372$.

BLAIS, J. R. 1958a. Effects of 1956 spring and summer temperatures on spruce budworm populations (Choristoneura fumiferana (Clem.)), in the Gaspé Peninsula. Can. Ent. 90: 354-361.

BLAIS, J. R. 1958b. The vulnerability of balsam fir to spruce budworm attack in northern Ontario with special reference to the physiological age of the tree. For. Chron. 34: 405-422.

BLAIS, J. R. and R. Martineau. 1960. A recent spruce budworm outbreak in the lower St. Lawrence and Gaspé with reference to aerial spraying operations. For. Chron. 36: 209-224.

BLAIS, J. R. 1962. Collection and analysis of radial-growth data from trees for evidence of past spruce budworm outbreaks. For. Chron. 38:474-484.

GREENBANK, D. O. 1956. The rôle of climate and dispersal in the initiation of outbreaks of the spruce budworm in New Brunswick. I. The rôle of climate. Can. J. Zool. 34: 453-476.

HALliDAY, W. C. D. and A. W. A. Brown. 1943. The distribution pattern of some important trees in Canada. Ecology 24:353-373.

HATCHER, R. J. 1964. Spruce budworm damage to balsam fir in immature stands, Quebec. For. Chron. 40:372-383.

LACHANCE, P. E. 1954. A study of the pulp and paper industry of the Province of Quebec in relation to its present and future wood supplies. Pulp Paper Mag. Can. 55. 276-332.

MOTT, D. G., L. D. NAIRN and J. A. Cook. 1957. Radial growth in forest trees and effects of insect defoliation. Forest Sci. 3: 286-304.

PILON, J. G. and J. R. BLAIS. 1961. Weather and outbreaks of the spruce budworm in the Province of Quebec from 1939 to 1956. Can. Ent. 93:118-123.

ROWE, J. S. 1959. Forest regions of Canada. Canada Dept. of North. Aff. and Nat. Res., For. Br., Bull. 123, 71 pp.

WEBB, F. E., D. R. MacDONALD and D. G. CAMERON. 1959. Aerial spraying against spruce budworm in New Brunswick - 1958. Bi-Mon. Prog. Rept., Div. For. Biol., Dept. Agr., Can., $15(1): 1-2$.

WELLINGTON, W. G., J. J. FETTES, K. B. TURNER and R. M. BELYEA. 1950. Physical and biological indicators of the development of outbreaks of the spruce budworm. Choristoneura fumiferana (Clem.), and the forest tent caterpillar, Malacosoma disstria Hbn. Can. J. Zool. 30: 114-127. 